\section{Cork Substitutes}

As a result of the War, imports of cork have almost, if not entirely, ceased in various parts of the world. Consequently, ingenuity has had to be exercised in providing substitutes. For obvious reasons stoppers for bottles were one of the earliest articles for which replacement was required. One of the countries effected was India, where the imports of cork from Europe very soon ceased, and the need for a substitute material for use as stoppers in different types of bottles, and as liners for bottle crowns and so forth, became keenly felt. The Forest Research Institute at Dehra Dun took up the matter, as explained in a Leaflet No. 6, Utilisation ("Note on Some Experiments on Cork Substitutes", by Dr. N. Narayanamurti, J. N. Pande and D. C. Roy (Research Institute, Dehra Dun, 1941). Experiments were conducted on the production of corks made of wood, composition corks made of disintegrated tree barks and pith corks for hypodermic tabloid tubes. So far, experiments have shown the following suitable sub. stitutes. Bottle stoppers : stoppers of Cryptomeria japonica wood suitably slotted and softened by chemical treatment; crown cork liners: composite cork made from Erythrina suberosa bark and bagasse fibre have been found suitable; corks for tabloid tubes: paraffin-impregnated sola pith is suitable. The methods of manufacture of these substitutes are described.

\section{Nature Reserves Investigation Committee}

A Nature Reserves Investigation Committee has been established with the following membership : Sir Lawrence Chubb (chairman), Mr. G. Dent, Capt. C. Diver, Mr. J. C. F. Fryer, Mr. N. B. Kinnear, Prof. W. H. Pearsall, Dr. J. Ramsbottom, Prof. James Ritchie, Prof. E. J. Salisbury, Dr. G. F. Herbert Smith (honorary secretary), British Museum (Natural History), London, S.W.7.

The object of the Committee is to examine proposals for the establishment of nature reserves as part of any general scheme of national planning; and to obtain information from such bodies or persons as may be directly or indirectly concerned with the formation, organization, or administration of nature reserves or sanctuaries. In particular, the Committee will inquire into the types and approximate areas of reserves and sanctuaries which should be provided to ensure the preservation of communities or species; the species of plants and animals which are in danger unless special arrangements are made to secure their preservation and reproduction; the localities where such reserves and sanctuaries should be situated; the extent to which the public should have access to the various reserves; and the most appropriate methods for acquiring, financing and administering the reserves.

\section{Scientific Film Conference}

The first Scientific Film Conference in Great Britain met in the County Buildings, Ayr, during August 1 and 2. In Ayrshire there are four scientific film societies in operation, while an Army and an Air Force camp also arrange periodic shows of scientific films. The Conference was attended by forty-three delegates appointed by the film societies, universities and technical colleges, research institutes, technical departments of local government bodies and the Association of Scientific Workers. Dr. Norman Wright, director of the Hannah Dairy Research
Institute, Mr. Arthur Elton and Dr. Blodwen Lloyd presided at the three sessions held on August 1. The delegates decided to form a National Federation of Scientific Film Societies, which would co-ordinate the activities of a Scottish and an English association of such societies. The great need for the increased production and showing of good scientific films was stressed by Mr. Elton (Ministry of Information) during a symposium on "The Scientific Film", to which Miss Mary Field (Gaumont British), Dr. A. Clow (University of Aberdeen), Mr. Stewart Paterson (Ardrossan S.F.S.) and Dr. B. Lloyd (Glasgow S.F.S.), among others, contributed papers. There was general approval of a resolution that both the winning of the War and the planning of post-war reconstruction require the application of the scientific method, and that a wider understanding of this method could most readily be achieved through the medium of the film.

\section{Library of the Philippines}

Colonel C. P. Romulo, formerly a publisher in Manila, now aide-de-camp to General MacArthur, has reported in the New York Herald-Tribune of July 17 that the Japanese have destroyed by fire the Library of the Philippines at Manila. According to Colonel Romulo, the aim of this vandalism is to obliterate all reference to the United States and Great Britain and anything savouring of AngloSaxon culture and democracy. With this aim in view, the occupying forces have formed a Text-book Board comprising seven Japanese and three Filipinos, which is expected to see that no reference to the above countries or culture shall be available in schools. Colonel Romulo was awarded the Pulitzer Prize for 1941 for his interpretative articles on Japanese aims. It will be remembered that university buildings in Manila escaped damage during the attack on Manila (NATuRe, July 4, p. 20), and it would appear that the destruction of the Library referred to above occurred after the Japanese occupation

\section{Bournville Village Trust}

UNDER the title "Sixty Years of Planning: the Bournville Experiment", the trustees of the Bournville Village Trust have issued an admirable illustrated account of the development of Bournville from the building of the factory there by Richard and George Cadbury in 1879, when the first houses were also built to provide accommodation for those of the workmen who had to live near the factory (Bournville Village Trust, Birmingham 30). Bournville Village as we know it to-day dates from 1895, and the land and houses were transferred to an independent body, the Bournville Village Trust, when the success of the Bournville Estate seemed assured in 1900. The trust deed laid down the broad lines of future development, and this pamphlet shows the many sides of the work at Bournville in their true perspective. Housing schemes, the reconditioning of slum property and the planning of both municipal and private developments, as well as research into building and planning properties all find some mention in a book which is of real topical value apart from its historical aspect as a popular account of a great pioneer development. The illustrations of amenities, community activities, the planning of and provision for recreation, as well as for cultural needs, the treatment of transport and road problems and the preservation of the countryside show what is possible 
with vision and forethought, and should give $\mathbf{a}$ further stimulus to that growing movement to use to the full the opportunities which the tragedies of war itself now afford us of rectifying the mistakes and failures of the past and our failure to plan harmoniously either the industrial towns or the countryside of Great Britain.

\section{Indian Farming}

THE journal Indian Farming, now in its third year of publication, is issued by the Imperial Council of Agricultural Research of India and is a praiseworthy attempt to bridge the gap between cultivator and scientific worker. It is a monthly with a pleasant appearance of format and is copiously illustrated. It includes articles on breeds of Indian livestock, livestock products and crops, and the erosion problem receives due recognition. Shorter articles and reviews from all parts of the country help to provide a reasonably full conspectus of Indian agricultural problems and of the manner in which technical effort is being directed to meet them. All original papers have a practical bias, as, for example, the recent paper entitled "More Light on the Red-spot Epidemic", by B. L. Chona and G. W. Padwick $(3,70-73 ; 1942)$. This gives details of the infection of sugar-cane by Colletotrichum falcatum, which has led to sudden and almost complete failure of the variety Co 213 over a wide area : a new strain of the fungus, not observed before the epidemic, is described. A note on animal quarantine in the Provinces and States discloses that the Central Provinces alone have anything like a comprehensive organization. As a good example of the educative article may be mentioned "Propagation of the Apple in Kumaun", by R. S. Singh. The solar treatment of loose smut of wheat-a method evolved at Lyallpur from Jensen's hot-water treatment-has been de. scribed by J. C. Luthra $(2,416 ; 1941)$; it is very effective and furnishes a striking instance of extreme simplicity in a control measure well adapted for farmers. A new heavy-yielding and strong-growing variety of sugar-cane ( $\mathrm{Co} 421$ ), described by Ch. Kh. Mohammad (2, 140;1941), seems to be especially suited to the Punjab, and its seed is being multiplied as rapidly as possible. V. $R$. Rajagopalan (2, 13639 ; 1942) has established calcium deficiency as the cause of an outbreak of non-bacterial abortion in equines. Indian Farming gives much attention to processing and marketing, including the canning and dairying industries, and the grading of eggs and oranges, and whenever possible simple devices adapted to Indian conditions are described in order that quality shall be improved.

\section{Montesquieu and Medicine}

THE issue of the bilingual Schweizerische Medizinische Wochenschrift of May 2 contains an article in French by Dr. Camille Dreyfus of Mulhouse on this subject, in which he declares that the author of "L'Esprit des Lois" and the "Lettres Persanes" deserves a place in the history of medicine which has not yet been accorded to him. In 1718, the Academy of Bordeaux, of which Montesquieu had been elected a member two years previously, had chosen as the subject of a prize "The use of the renal or atrabiliary capsules", the modern equivalent of which would be "The physiology of the suprarenal capsules". Montesquieu made a report on the essays submitted, in which he showed that none of the competitors was worthy of the prize, which was, therefore, not awarded. His "Observations sur l'Histoire Naturelle", which he submitted to the Academy in 1721, contained microscopical studies of the pigmentations of insects, the parasitic life of the mistletoe, the abdominal circulation of the frog, the foramen ovule and ductus Botalli and experimental researches on the nutrition value of vegetables. In spite of his satires on medical practitioners in "L'Esprit des Lois" and the "Lettres Persanes", it would be wrong to suppose that he was prejudiced against the medical profession generally. In a letter to his friend the Abbé de Guasco, he expressed his admiration and affection for Van Swieten, the celebrated Dutch physician, whom Maria Theresa had invited to Vienna to reorganize medical education. Montesquieu was also a friend of the Chevalier Louis de Jancourt, who contributed articles on physiology and pathology to the "Encyclopédie". The high esteem in which Montesquieu himself was held by a leading medical man of the time is shown by the following appreciation of him by Antoine Portal, the celebrated professor of anatomy at the Collège de France and the Jardin du Roy: "If Montesquieu had devoted himself to the study of anatomy he would perhaps have advanced this science as much as he did moral science." In conclusion, Dr. Dreyfus relates that Montesquieu was the author of a thought which alone should win him immortality: "If I knew something useful to my country but injurious to Europe and the human race, I should regard it as a crime."

\section{American Health in Early War Months}

According to an editorial in the April issue of the Statistical Bulletin, the organ of the Metropolitan Life Insurance Company of New York, the United States have enjoyed a period of remarkably good health during the months they have been at war. An improvement in mortality-rate during the first three months of 1942 over that in 1941 was reported for almost all the important causes of death, and no less than nine diseases have shown death-rates lower than ever before. These diseases included not only typhoid fever, scarlet fever, diphtheria, whooping cough, syphilis and appendicitis, but also such important diseases as influenza, pneumonia and tuberculosis, in which the mortality has been low in recent years. The 1942 record for the most important diseases of middle and later life, namely, cancer, diabetes and cardiovascular renal diseases is favourable compared with that of 1941, the death-rate from diabetes being down 10 per cent and cancer and the cardiovascular renal diseases each 3 per cent. One of the few diseases to show a rise in 1942 as compared with 1941 are diseases of the puerperal state, of which the rate rose from $4 \cdot 1$ to $4 \cdot 5$ per 100,000 , or approximately 10 per cent. It is probable that the increase was due to the rise in the birth-rate and in the number of women exposed to the risks of pregnancy and child-birth. Another group of conditions in which there has been an increase in the death-rate were external causes, with the exception of suicide, which had declined. Homicides and accidents, especially accidents due to motor-vehicles, were higher than in 1941. The war deaths reported to the Company in the first three months of 1942, amounting to 5 per 100,000 , accounted for a part of the rise in the death-rate from external causes. 